\title{
Towards a new era of regionalism in Italy? A comparative perspective on autonomy referendums
}

\author{
Arianna Giovannini* and Davide Vampa**
}

\begin{abstract}
Referendums on regional autonomy are rare events in European politics but are likely to produce important political and institutional effects. This article provides the first systematic account of the autonomy referendums held in October 2017 in Lombardy and Veneto (Italy), and seeks to: i) explore the origins of autonomy referendums, placing them within a wider comparative framework of similar exercises across Western European countries; ii) explain their political, economic, social and cultural roots; iii) analyze the campaigns and the results, assessing variations across and within the two regions; iv) reflect on the political and institutional implications of the referendums, and evaluate the extent to which they could lead to a new era of regionalism in Italy, characterized by further asymmetries and fragmentation both at political and institutional level. Far from being an isolated case, Italy can provide useful insights into the new politics of regionalism and federalism in Western Europe. We also suggest that a more nuanced approach to the study of regionalism should not only focus on regional-central relations but should also account for tensions existing within regions (e.g. regional vs. local levels and cities vs. provinces).
\end{abstract}

Keywords: multilevel governance, regional governance, referendum, autonomy, territorial mobilization, devolution, institutional asymmetries, centre-periphery cleavage

*Department of Politics, People and Place, De Montfort University, Leicester, UK

** Corresponding author (‥vampa@aston.ac.uk); School of Languages and Social Sciences, Aston University, Birmingham, UK

Arianna Giovannini is VC2020 Senior Lecturer in Local Politics at the Department of Politics and Public Policy, De Montfort University (UK), where she the Deputy Director of the Local Governance Research Centre (LGRC). Arianna's research concentrates on local and territorial politics in the UK and in comparative perspective. She is particularly interested in processes of devolution, governance rescaling and regionalism. She's publishes widely on these topics, and her latest book (Developing England's North: the Political Economy of the Northern Powerhouse) was published by Palgrave in 2018. She is a Fellow of the RSA, an elected Trustee of the UK Political Studies Association (PSA), the Chair of the PSA Italian Politics Specialist Group and the co-convenor of the PSA Local Politics Specialist Groups. Orcid ID: https://orcid.org/0000-0002-3301-0681

Davide Vampa is a Lecturer in Politics and IR at Aston University. Previously he was a Senior Lecturer in Public Policy at De Montfort University in Leicester and Assistant Professor in Quantitative Methods at The University of Nottingham. He completed his doctorate at the European University Institute in Florence. His research interests focus on the link between territorial party politics and public policy. He recently published a monograph on the regional 
politics of welfare in Italy, Spain and Great Britain (Palgrave Macmillan). He has also published articles and book chapters on multi-level politics, social policy, changing local representation and populist parties in Western Europe. Orcid ID: https://orcid.org/0000-0001-5983-5422 


\section{Introduction}

Over the last decades, regions have become increasingly important political entities in European governance (Keating, 2013). As shown by Hooghe et al. (2010) this 'shift' was particularly significant in Western European countries such as the UK, Italy, Spain and even France, which were previously characterized by a long tradition of over-centralization. In some cases, citizens have been asked to express their support for processes of regional government (re)structuring. Thus, regional autonomy (or 'devolution') referendums have been crucial moments in the construction of regions as political and policy-making arenas. But what are the drivers of this type of referendum and what kind of political and institutional effects can they have?

This article aims to address these questions, assessing the political and institutional origins, dynamics and impact of regional autonomy referendums - focusing on the two votes held in Veneto and Lombardy in October 2017. So far, no academic study has provided a systematic analysis of these two cases, and compared them to similar autonomy referendums held across Western European countries since the 1970s. Our study bridges this gap, whilst also providing a cross-country comparative framework, often missing in studies on individual regions and useful for future research.

The article starts with an overview of the process of regionalisation in Italy, to set the scene for the two cases. We then examine the origins of autonomy referendums by considering different European experiences. We compare and classify autonomy referendums based on their proponents and their key goals, to position the case of Italy in a wider comparative context. We then focus on Veneto and Lombardy and assess the paths leading to the autonomy referendums in the two regions, showing the underpinning differences. Drawing 
on this, we analyse the referendum campaigns and results, paying particular attention to variation in turnout across and within regions and dualism between cities and provinces, and between large and small towns. An analysis of the political and institutional consequences of the referendums is followed by a final section with concluding remarks.

\section{Regionalization in Italy}

Regionalization in Italy has developed incrementally. The 1948 constitution set a framework for an asymmetrical regional system, which provided for the creation of both 'ordinary' and 'special' statute regions. Regional assemblies in 15 'ordinary statute' regions were officially established only in 1970 but, in practice, regional governments remained quite weak until the 1990s. The gap between them and the five 'special statute' regions (Sicily, Sardinia, Friuli Venetia Giulia, Trentino-South Tyrol and Aosta Valley), which were created much earlier and enjoyed higher levels of decision-making and fiscal autonomy, was significant. Several interconnected factors contributed to an acceleration of regionalization in Italy from the early 1990s. Firstly, the collapse of 'established' party system called into question the very pillars of the Italian state and its organization. Secondly, this crisis opened new political spaces for 'anti-establishment' actors, such as the Northern League (NL). This regionalist populist party (McDonnell, 2006) denounced the corruption of the national political elite and mobilized against redistribution of resources from the wealthy North to the poor South (Fargion, 2005). In addition, whilst territorial mobilization was mainly concentrated in the North, the whole country was affected by a series of reforms, aimed at strengthening regional governments. A key step in this direction was the Constitutional reform approved via referendum in 2001 . This resulted in a Constitutional Law (18 October 2001, N. 3), which modified the Title V of the Constitution, dedicated to territorial autonomies - introducing substantial changes in the 
allocation of powers between state and regions (Vandelli, 2014). Crucially, this involved a revision of Article 116, allowing the attribution of particular forms and conditions of autonomy to ordinary status regions' (Clause 3 ) and thus inscribing a clause for potential asymmetric regionalism in the Constitution. However, the implementation of these reforms was far from unproblematic: it remained incomplete (see Vandelli, 2004) and, in practice, none of the Italian regions made use of the new Article 116 Clause 3 provisions. The 2005 Constitutional reform also aimed, among other things, to increase the authority of regions but it was rejected in a referendum in 2006.

Generally, some asymmetries between ordinary and special statute regions did remain and, as we show below, different composition of financing played an important role in the lead-up to the referendums. However, ordinary regions were granted the same formal powers. In this respect, Italy is dissimilar to cases such as the UK, where the rise of regionalist and sub-state national demands led to increasing institutional differentiation and the creation of devolved administrations with intrinsically asymmetric powers in Scotland, Wales and Northern Ireland (Mitchell, 2010) but not in England.

The fact that the regionalization process in Italy retained a degree of institutional uniformity and symmetry among the 15 ordinary statute regions does not mean that it contributed to reducing or stabilising territorial inequalities. In practice, regions made different use of formally similar powers and institutional tools, and

de iure symmetry has not ... prevented de facto asymmetry between ordinary regions in their exercise of policy competences, owing to strong variations in their administrative and financial capacity as well as institutional performance (Palermo and Wilson, 2014, p. 511). 
This was already noted by Putnam (1993) in his seminal study on the performance of regional institutions in Italy, which despite having similar formal powers, might work very differently. He observed that the governments of central-northern Italian regions with high levels of 'social capital' are 'efficient in their internal operation, creative in their policy initiatives and effective in implementing those initiatives' (Putnam, 1993, p. 81). According to him, civic traditions also 'turn out to be a uniformly powerful predictor of present levels of socioeconomic development' (Putnam, 1993, p. 156). Hence, in practice, more powerful regional institutions interacting with significant discrepancies in civic culture and socioeconomic development have contributed to widening the gap between Northern and Southern Italian regions. Recent studies have shown that differences in institutional performance and policy outcomes remain significant across regions and have actually increased (Vassallo, 2013; Vampa, 2016).

Thus, regionalization does not seem to have reduced territorial inequality in Italy and political relations among regions have been characterized by increasing tensions. In a context of austerity and economic uncertainty, the precarious institutional equilibrium reached in the early 2000s was increasingly challenged by opposing pressures. Successive governments have sought to re-establish the coordinating role of the state and tried to recentralize policy competencies. Indeed, the constitutional reform rejected in the 2016 referendum (Ceccarini \& Bordignon, 2017) would have produced a shift towards a more cooperative and centralized form of regionalism. In the wake of this wave of (re)centralisation that was aggravated by the economic crisis, some regions in the North have demanded formal recognition of crossregional differences, which, in the view of their leaders, de facto already exist. Such bottom up demands push the very issues that the 2001 Constitutional reform struggled to put into practice to the top of the agenda. Veneto and Lombardy have done so by resorting for the 
first time to regional autonomy referendums, which were held on 22 October 2017 (EmiliaRomagna too moved in this direction, but without calling a popular consultation as this is not a statutory constitutional requirement). Although only consultative, these referendums represent a clarion call to introduce new elements of regional differentiation into the territorial structure of the Italian institutional system. Despite their non-binding nature, the referendums have a strong political value. Their proponents aimed to use the results in a strategic manner, as a means to exercise pressure on central government and add a popular mandate to their demands for further regional autonomy. After having traced the background and processes that led to the autonomy referendums of October 2017, in the next section we place these within a broader comparative perspective.

\section{The origins of autonomy referendums}

Autonomy (or 'devolution') referendums are a particular sub-group of referendums. We define them as a general vote by the electorate of a sub-state region ${ }^{1}$ on a political question, which focuses on the transfer of authority from the centre to new or already existing institutions operating in that region. Therefore this category does not include 'independence' referendums, which go beyond simple transfer of authority and, if successful, would lead to the full secession of a region (Oklpocic, 2012). Autonomy referendums are also different from 'state-wide' constitutional referendums, which involve the whole electorate of a country (and not just a specific constituency) and are aimed at ratifying or introduce changes in the national constitution (Chambers, 2001).

Autonomy referendums can be called by central governments or parliaments, when there are no political institutions at the regional level (in fact, these referendums might be aimed at introducing such architectures), or by existing regional governments (or legislative bodies) 
themselves. In the latter case, the legislation needed to hold a referendum can either be passed unilaterally by regional institutions or it might require the approval of both national and regional political bodies. The $1997^{2}$ devolution referendum in Scotland, Wales, as well as the 2004 one in the North East of England, were called by central government because no representative institutions existed in these contexts. Of course, in the case of Scotland and, to a lesser extent, Wales, demands for a devolution referendum came from important political and civil society sectors and central government addressed these calls by approving new legislation (Bogdanor, 2001). Weaker demands for devolution had already emerged in the 1970s and the Callaghan government introduced legislation for two devolution referendums, which were unsuccessful. The North East of England experienced a more 'topdown' process in which central government played a dominant role and regional campaigns were limited in their impact (Willett \& Giovannini, 2014).

There are also cases of autonomy referendums that emerged from the interaction between regional and central political institutions. The 2006 Catalan referendum (Colino, 2009) and the 2011 Welsh referendum (Wyn Jones \& Scully, 2012) are clear examples of processes involving different levels of government. In Spain other autonomy referendums had already been held in the Basque Country, Catalonia, Galicia and Andalusia to ratify the new autonomy statutes approved between 1979 and 1981 (Andalusia was the only one in which the referendum was mandatory according to art. 151 of the Constitution and held another referendum to approve a new autonomy statute in 2007). Unlike the Scottish and Welsh referendums of 1979, these referendums were the outcome of a more interactive process between national and regional actors. 
The Veneto and Lombardy referendums are quite peculiar in the European context, as shown in Figure 1, which helps us locate different autonomy referendums on a continuum ranging from full central control of the process to full regional initiative. Indeed, they were fully promoted by the two regional governments without any involvement of central authorities. The Italian Constitution (Art. 116, Title V - modified through constitutional referendum in 2001) allows any region to request wider autonomy from the centre - although, to date, its implementation has remained dormant and no other Italian region ever made use of this provision $^{3}$. In the case of Veneto and Lombardy referendums, no official discussions with central state institutions were held before the vote. Only the 2013 referendum in Alsace had a similar 'unilateral' nature. Yet this is a borderline case of an 'autonomy' referendum since it was aimed at strengthening the region vis-à-vis departments (which are a legacy of revolutionary and Napoleonic centralism). The result would have led to 'special' territorial arrangements in the French region but not to substantial further autonomy, although opponents of the reform highlighted the potential threat posed by a more powerful Alsatian region to French unity (Kleinschmager, 2013).

[Figure 1 here]

Autonomy referendums may also have different content. They may be linked to reforms that have already been approved and need to be ratified or they may ask voters whether a new reform process should be started (the former are usually legally binding whereas the latter are consultative). Additionally they may be aimed at introducing new institutions (e.g. regional parliaments) and/or transferring policy-making or fiscal powers to regions. Table 1 provides an overview of the referendums discussed above. 
The Venetian and Lombard referendums aimed at starting a process rather than ratifying specific legislation approved by regional or national authorities. They mainly focused on transferring policy-making and fiscal powers to existing institutions. The 1997 referendums in Wales and Scotland also aimed at starting a process but, unlike the Italian referendums, they focused on the creation of completely new institutions receiving new powers from Westminster. In Spain, referendums held in the 1970s and 1980s aimed at establishing new institutions and devolving powers by implementing reforms that had already been approved by regional and/or national parliaments. Additional reform processes that occurred in the 2000s were ratified by regional referendums.

[Table 1 here]

The issue of fiscal autonomy was particularly relevant in the Lombard and Venetian cases. For instance, during the referendum campaign, the regional government of Lombardy published an official document presenting key facts and figures (Regione Lombardia, 2017). Much emphasis was placed on Lombardy's negative net fiscal balance. The gap between total spending and revenue raised in Lombardy is in fact substantial. Lombardy has a revenue surplus of 54 billion euros that is spent by the central government in other regions. The document compares the Lombard figure to those of Catalonia (8 billion euros), and Bavaria (1.5 billion euros).

Asymmetrical arrangements which grant more fiscal autonomy to neighbouring special statute regions such as Trentino-South Tyrol and Friuli Venetia Giulia, have further exacerbated the political debate around regional financing systems in Veneto and Lombardy. A parallel can be drawn between Italy and Spain. In the latter, Catalonia has expressed increasing dissatisfaction with arrangements that exclude this region from the special fiscal 
regime, which applies to the Basque Country and Navarra. The link between regional fiscal autonomy and territorial politics has become particularly important in Spain. As shown by Gray (2016, p. 19), different regional financing models have 'contributed to contemporary shifts in the Basque and Catalan nationalist parties' territorial agendas, understood as their goals regarding the relationship of their respective regions to the Spanish state'. Similarly, the issue of 'fiscal federalism' was highly politicized by the NL and its representatives in Lombardy and Veneto, particularly after the party's attempt to introduce 'fiscal federalism' (Law N. 42/2009) during its governmental experience at the national level. This partly failed due to changes in the political and economic context, namely the euro-crisis and formation of a new technocratic government.

This suggests that, in Italy, the existence of institutional asymmetries - de iure between ordinary and special statute regions, de facto between rich and poor ordinary statute regions - has interacted with political factors. It is not a coincidence that the two regions holding autonomy referendums have traditionally been the core constituencies of the strongest regionalist party in the country, the Northern League (Diamanti, 1996). Crucially, Veneto and Lombardy are also among the richest Italian regions. Indeed, since its creation in 1991, the NL's agenda was predominantly defined by socio-economic issues - stressing how wealthier regions in the North such as Lombardy and Veneto, and their dynamic economies, were being 'exploited' by the central government. In time, the NL also started promoting the idea of an 'imagined community' (Anderson, 1991) of the northern regions, with a distinctive homeland (Padania) - linking these to its claims for autonomy. However, the NL framed these aspects within a narrative of 'individualism, hard work and free market values' (Ginsborg, 1996, p. 30) as the distinctive principles of northern Italians. 
Overall, these factors point to the presence of a clear intersection between institutional asymmetries, identity politics and its mobilization and socio-economic dynamics, which have coalesced and helped shape the narrative of 'distinctiveness' underpinning autonomy referendums in Lombardy and Veneto (see fig. 2). The next section will shed light on this, assessing the contextual factors on which support for autonomy referendums was built in the two regions.

[Figure 2 here]

\section{Assessing distinctiveness: the roots of autonomy claims in Lombardy and Veneto}

The roots of autonomy claims in Lombardy and Veneto are connected with the long history of distinctiveness that characterizes them. The broad framework of the North-South divide helps to understand this. In short, the presence of a longstanding social and economic gap between a 'wealthy North' and a 'sluggish South' within Italy has permeated both political discourses and popular perceptions. In this way, local communities in Lombardy and Veneto have increasingly bought into the argument that their high levels of contributions to the national GDP is unfairly redistributed across the whole country, supporting, to their detriment, areas lagging behind (especially in the South). This narrative has, in turn, fed into a widespread perception that regions like Lombardy and Veneto have been exploited by central government - leading to a growing sense of hostility towards state institutions and traditional political elites (Cento Bull \& Gilbert, 2001). This helps explain the salience and persistence of the so-called 'northern question' (Diamanti, 1996). It could be argued, therefore, that the autonomy referendums held in Lombardy and Veneto graft onto the narrative of the North-South divide and provide a further attempt at addressing the alleged 'fiscal injustice' perpetrated by the central state. 
Yet, the North-South divide provides only a partial interpretive framework. Indeed, it would be more accurate to differentiate between Veneto and Lombardy when looking at the roots of their support for autonomy claims. As illustrated in the next section, whilst both regions returned a vote in favour of further autonomy, the bulk and distribution of support was quite diversified between as well as within them. As noted by Diamanti (2017) the geo-political category 'Lombardo-Veneto' used by some commentators does not hold. Whilst associated by a common 'malaise' based on economic motifs and dissatisfaction with state institutions, Veneto and Lombardy do not share either a common history or identity basis - and the cultural, political and economic traits that shape their social fabric remain profoundly diverse.

Lombardy itself is far from homogeneous. It is characterized by internal economic and political differences, which have not disappeared in the 1990s and 2000s, when regional identity assumed increasing political relevance. At the economic level, a clear split can be observed between the metropolitan area of Milan, with its large enterprises and strong finance, communication and service sectors, and a set of 'hinterlands' based on diverse sectors, from agriculture to mall and medium enterprises (SMEs). Perhaps as a consequence of this, Lombardy also lacks a unifying political sub-culture (Trigilia, 1986) and three or four distinctive political areas can be identified, with the NL being particularly strong in the alpine and rural parts of the region.

Despite experiencing a deep leadership crisis, the NL won the Presidency of Lombardy in 2013 with Roberto Maroni, thanks to the support of a broader coalition of parties and interest groups, which placed relatively little emphasis on autonomy, let alone independence. In previous years, during the leadership of Umberto Bossi, the NL had never been able to fully interpret the demands coming from a very complex and politically plural region like Lombardy 
and had represented a very specific, and far from majoritarian, segment of local society. The widespread awareness of the economic exceptionalism of a region that many Lombards call the 'Italian Powerhouse' failed to translate into a consistent and politicized regional identity. This helps to explain why the 2017 autonomy referendum campaign was mainly based on 'technocratic' and 'economic' issues, emphasising the virtuous character of the region and the fact that its economic contribution to the national system should be institutionally recognized (Regione Lombardia, 2017).

Veneto is characterized by a different set of economic, cultural and political traits. In essence, despite some variations, for the most part the economic fabric of the region is embedded in a longstanding system of (successful) SMEs. Crucially, this model of economic development is tightly connected to social, cultural and political dimensions. Most of Veneto's SMEs are family-led. They are also part of established networks of associations, structures and initiatives, which operate across the main sectors of local social and individual life (Diamanti, 1996; Diamanti \& Riccamboni, 1992; Trigilia, 1991). This, in turn, generates a system of social norms and values coherent with the local model of economic development, based on the pillars of work, family and community (Diamanti, 1996). As such, the 'distinctiveness' of Veneto lies in a strong cohesion between productive systems and local communities as these, in practice, overlap with one another. Moreover, the presence of strong linguistic specificity - with a past written and literary tradition, still reflected in the wide use of dialect in everyday life - adds a further element of distinctiveness, which cannot be found in Lombardy.

After the collapse of the Christian Democratic party in the 1990s, the Venetian NL could rely on this pre-existing political sub-culture, dense social networks and identity markers to give voice to and, simultaneously, shape a new territorial identity. In recent years, particularly 
under the leadership of the current regional president Luca Zaia, the party managed to consolidate its position as the dominant political force at regional and sub-regional levels. Thus, thanks to a mix of structural factors and political entrepreneurship, territorial mobilization in Veneto has developed at a deeper political and social level than in Lombardy and also adopted a more radical discourse.

For instance, in 2014 autonomous regional groups staged a referendum on Venetian independence. This vote was unconstitutional, it was organized in an informal way, and it was not recognized by public institutions (Giovannini, 2014). According to Demos\&Pi (2014) almost half of the Venetian population participated in the initiative, and the majority of voters from all political parties supported independence. The centre-left Democratic Party (PD) was the only exception but, remarkably, more than one third of its voters expressed proindependence views (Demos\&Pi, 2014).

The organizers drew on historical and cultural messages in their campaign (e.g. flying the flag of the ancient Venetian Republic, using dialect as a surrogate for a regional language). However, research shows that the bulk of support for the pro-independence cause was not rooted in a desire for self-determination (Demos\&Pi, 2014). Instead, the vote was driven by socio-economic factors and by a desire to see 'Venetian distinctiveness' being recognized. This links to the previously mentioned sense of resentment towards the central state and its institutions, which have long being perceived as unable to represent and cater for Veneto. These feelings were exacerbated by the economic crisis, which widened the perceived sense of 'injustice' towards the system of fiscal redistribution across Italy and, crucially, undermined the 'pillars' of Veneto's socio-economic fabric (work, community, family). 
The autonomy referendum promoted by the Venetian regional government in 2017 grafts onto this narrative, and aimed to address societal demands stemming from it. Indeed, the Venetian political class showed awareness of the sense of frustration of an area that perceives itself as 'hard done by' central government (Diamanti, 2017) - and used the referendums as a means to reverse this process.

Overall, support for autonomy in Lombardy and Veneto is rooted in a logic of entrenched socio-economic interests and values, which are shaped by the shared, overarching NorthSouth divide narrative, as well as by specific elements of regional distinctiveness. As such, autonomy claims in the two areas are tightly linked to their distinctive cultural, political and socio-economic contexts. These differences manifested themselves in and impacted on the referendum campaigns and their results. The next section will analyse these, focusing on the driving forces as well as the cleavages underpinning the vote in Lombardy and Veneto.

\section{The referendums: campaigns and results}

\section{Campaigns}

The presidents of Veneto (Luca Zaia) and Lombardy (Roberto Maroni) held the referendums on the same day (22 October 2017), thus reinforcing the idea that, despite the existing differences highlighted above, a political axis between the largest and richest regions of northern Italy was created. This was not so difficult to achieve: both Maroni and Zaia belong to the same party $(\mathrm{NL})$ and are sensitive to issues of regional autonomy and federalism. Being prominent regional leaders allowed Maroni and Zaia to use the referendums as a platform to showcase the NL as the main political actor concerned with the needs and future of Lombardy and Veneto. 
However, the vote was called at a time of deep ideological and organizational transformations within the NL. Following the downfall of its founding father Umberto Bossi and the NL's electoral collapse of 2013 , the new leader Salvini radically reframed the territorial dimension of the party's populist message (Albertazzi, Giovannini and Seddone, 2018), shifting the centre-periphery cleavage that defined the NL towards the European level. Thus, 'Italy as a whole [is now] seen as part of a "peripheral" region in a European "super-state" dominated by the "core" countries of central-northern Europe' (Vampa 2017, p. 34). In this way, Salvini has transformed the party into a 'national league' with a nativist-nationalist, rather than regionalist, agenda (Albertazzi, Giovannini and Seddone, 2018) - as epitomised by the removal of the term 'North' from the party symbol.

The 'regionalist struggle' revived by the two NL regional presidents through the referendum is clearly inconsistent with Salvini's 'national turn'. Although formally supporting the referendums, the national leader conducted a rather lukewarm campaign and jumped on the bandwagon only after the vote was won (Albertazzi, Giovannini and Seddone, 2018). These latent tensions between the regional and national party were put under the spotlight by the autonomy referendums. And yet, Maroni and Zaia ran well-organized and focused campaigns, which dominated the headlines of local, regional as well as national media, gaining substantial traction.

In Lombardy, Maroni launched a campaign focused on the idea of 'regional uniqueness'. This was outlined in a document produced by the regional government emphatically entitled 'Why Lombardy is Special' (Regione Lombardia, 2017), which was widely promoted across the region. The campaign concentrated on Lombardy's areas of excellence at national and European level, highlighting regional strengths in terms of economic development, 
healthcare, welfare, culture, tourism and territory (Regione Lombardia, 2017). In essence, this developed a 'rational narrative' around the idea that Lombardy is an exceptionally virtuous region that deserves more autonomy, especially in fiscal terms. This 'instrumental', rather than emotional or 'ideological', rhetoric (Atkins, 2016) was also evident in the leaflets distributed by the NL, which placed almost exclusive emphasis on 'territorial resources' (Lega Nord Lombardy, 2017)

Thus, economic issues - rather than those of culture or identity - dominated the proautonomy discourse and shaped the agenda. This 'rational' approach aimed at winning the minds, rather than the hearts, of the Lombard electorate - and is consistent with the idea of economic distinctiveness that characterizes the region discussed in the previous section. It was also reflected in the wording of the referendum question on the ballot, which can be described at best as technocratic:

"In view of its distinctiveness, and within a context of national unity, should the Lombardy Region start the institutional initiatives necessary to request that the State attributes to it further forms and special conditions of autonomy as per the Article 116, third clause, of the Constitution, and with reference to any legislative matter through which such procedure is allowed as per the Article above?"

Maroni was the main promoter of the campaigns - and yet, he portrayed the vote as a 'common battle that goes beyond political hues' and as a 'referendum for all Lombards' and not for his own or the NL's advantage (Anastasio, 2017).

In Veneto, like Lombardy, the regional governor led the campaign. The symbol of the 'Yes camp' included a banner of San Marco (the Saint Patron of Venice and symbol of the old Venetian Republic) and the slogan 'Autonomy Now'. The campaign narrative was built around 
a mix of 'emotive' themes (i.e. making clear reference to the 'glorious autonomous past' of the region - epitomized by the banner described above) and economic issues (emphasising that sense of 'neglected distinctiveness', 'fiscal injustice' and the need to break entrenched path-dependence of a central State that draws too heavily on the Venetian economy previously analysed). The referendum vote was portrayed as a 'unique, historic opportunity to give recognition to Veneto's traditional entrepreneurship, and transform it into concrete results for Venetian families and enterprises' (Corriere del Veneto, 2017). In this way, the campaign won both the hearts and the minds of voters - gaining wide support among local entrepreneurs' associations, trade unions and civil society organizations (Porcellato, 2017a), which, as previously outlined, play a key role in shaping the social fabric of the region. Significant emphasis was also placed on turnout: the promoters repeatedly underlined the importance of delivering a mass vote in favour of autonomy, so as to 'show central government that Veneto wants and deserves better' (Regione Veneto, 2017). This approach, recalling a political 'call to arms', was reflected in the referendum question, which was more straightforward and unambiguous than in Lombardy:

"Should the Veneto Region be attributed further forms and particular conditions of autonomy?"

Zaia's popularity was crucial in the campaign. The remarkable level of personal support that he enjoys across Veneto (Porcellato, 2017b) means that he could affect public opinion. Importantly, this consensus is cross party: it comes from a significant majority of NL voters, but includes also supporters of all main parties (Diamanti, 2017b). Zaia drew on traditional NL political messages (such as 'masters in our own homes' and 'no more money to Rome') which have, nonetheless, a wide-ranging appeal among local voters of all hues. He also repeatedly 
claimed that this was a 'referendum for all Venetians' (Diamanti, 2017b). This narrative gained considerable traction and, indeed, in the aftermath of the vote over 70 percent of the electors saw the results of the referendum as 'a victory for all Venetians' as opposed to a NL victory or a personal one for Zaia (Porcellato, 2017a).

Thus, thanks to the prominence of its regional governors and notwithstanding the latent frictions with the party's leadership, the NL played a key part in the referendum campaigns. However, no significant opposition emerged from other parties and, in both regions, the referendum campaigns were characterized by almost unanimous support for autonomy across a broad range of political actors. In Lombardy, PD's local leaders organized a proautonomy 'committee' of mayors and province presidents (True Autonomy for Lombardy, TAL), led by Bergamo's mayor Giorgio Gori. Although this name was chosen to mark its difference from Maroni's campaign and to distance itself to what was defined as 'NL's propaganda' (Montanari, 2017), TAL's message was of the same nature, supporting the view that Lombardy deserves more powers. In Veneto, too, local representatives of all political parties were largely in favour of autonomy and, overall, 18 'Yes committees' were created.

The absence of any real campaign against autonomy makes the Lombard and Venetian referendums stand out in comparison with the other European cases. Whilst small factions of the main parties at local level were sceptical about the referendum, these never took an organized form to overtly oppose autonomy. Rather than coalescing into 'No campaigns' these actors simply opted for boycotting the consultation by not voting. The most notable example is the former mayor of Milan Giuliano Pisapia - who called the referendum a 'political cheat' and declared that he would not vote (Senesi, 2017). 
Thus, the issue of autonomy gathered wide consensus, and the campaigns were not polarized. Instead, their leitmotif was the presence of a persisting tension between centralism and autonomy, which went beyond party political dynamics. And yet, national leaders of the same parties that supported autonomy at local level were, more often than not, against it. This, again, sheds light on a tension between local and national perception of centralist vs. autonomy discourses - which sees local leaders being closer to the latter and national ones to the former.

Lack of opposition made the results of both referendums quite predictable. However, as shown in the next section, electoral turnout, which can be used as an indicator of citizens' commitment to the autonomy cause, varied substantially between and within regions.

\section{Results}

The results of the two referendums are summarized in Table 2 . It can be immediately noticed that whilst both regions returned a plebiscitary support for autonomy, with a Yes vote above 95 percent, turnout figures were significantly different. Turnout in Veneto reached 57.2 percent, meaning that the absolute majority of eligible voters supported more autonomy. However, in Lombardy turnout was below 40 percent, suggesting a much lower mobilization. This can only partly be explained by the fact that a 50 percent turnout threshold was set for the Venetian referendum in order for the results to be considered valid, whereas no such requirement was established in Lombardy. Indeed, the political and socio-economic differences identified earlier in the article may also account for the marked discrepancy between the two regions. As noted by Diamanti (2017), the referendum results became an opportunity for Veneto to reassert its difference and distance itself not only from Rome but also from Milan. From a political perspective, in fact, Lombardy is in a much less 'peripheral' 
position than Veneto and is less affected by the competition from the special statute regions of the North-East.

[Table 2 here]

Figure 3 provides a comparative overview by considering autonomy referendums in other European countries, concentrating on levels of participation (horizontal axis) and the percentage of voters choosing the pro-autonomy option (vertical axis). Clearly, the Venetian referendum is among those in which strong support for autonomy is combined with widespread mobilization. In this category we can include the Basque and Catalan referendums in 1979 and the 1997 Scottish referendum, which marked crucial moments in the process of regionalization and devolution in Spain and the UK. Lombardy, in contrast, is a case of a strong pro-autonomy vote but in a context of weak political mobilization. Turnout in its referendum is among the lowest across Europe. It is similar to the Andalusian and Welsh referendums, which took place in 2007 and 2011 respectively and resulted in rather modest changes in centre-periphery relations (Wyn Jones \& Scully, 2012, pp. 110-111). Interestingly the previous Welsh referendum (1997), which led to the establishment of devolved institutions, is situated in the middle of the four sectors (turnout was significantly lower than in Scotland and the electorate was split in half), whilst the 1979 one is the only clear case of referendum in which relatively high levels of participation led to a clear rejection of the autonomy option. Lastly, the 2004 referendum in the North-East of England did not encourage high levels of mobilization and, since it was seen as part of a 'top-down', 'elitedriven' process (Willett \& Giovannini, 2014; see also Figure 1), it was rejected by a vast majority of the few who voted.

[Figure 3 here] 
An analysis based on 153 municipalities ${ }^{5}$ in Veneto and Lombardy provides also some insights into the socio-economic and political dynamics that were in place during the referendums. We are aware of the limits of this analysis but, to our knowledge, no other attempt has so far been made to map support for autonomy at sub-regional level in Lombardy and Veneto. Table 3 shows the results of a linear regression model. Cross-municipal variation in turnout ${ }^{6}$ is our dependent variable (measured in percentage points). The model includes various geographical, political and socio-economic independent variables, which may help us explain this variation. The first is a dummy variable comparing municipalities in Veneto and Lombardy. This is followed by the percentages obtained by the four main parties in the previous national election (2014 European election) across the municipalities. Variables measuring population size and per capita income are also included ${ }^{7}$. Both standardized and unstandardized coefficients are shown.

Even controlling for political, demographic and socio-economic factors, the difference between municipalities in Veneto and Lombardy remains substantial. On average, turnout in the municipalities of Veneto is 20 percentage points higher than in Lombardy. The standardized coefficient of this variable is the strongest one, suggesting that cross-regional differences play an important role in explaining cross-municipal variation. The second most important variable, as expected, is the electoral strength of the NL, which has a positive and statistically significant coefficient. Also the coefficient of the other main centre-right party, Berlusconi's Forza Italia (FI), which governs both regions with the NL, despite being smaller, is positive and statistically significant (although at the 0.05 level). The coefficients of the other two parties, the centre-left PD and the populist Five Star Movement (M5S) are also positive, but not statistically significant. These results confirm that there was no significant political opposition to the referendum. Wealthier municipalities seem to have been more active in the 
referendum and this may be due to the importance that fiscal autonomy played in the campaign, as these are the areas that make a greater contribution to the territorial redistribution of resources. Consequently, they are more likely to support processes of fiscal federalization that weaken equalization mechanisms. Lastly, participation was significantly stronger in smaller municipalities. The population size coefficient is negative, suggesting that the larger the municipality, the lower the turnout in the referendum.

[Table 3 here]

The latter result seems to point to a general divide between large urban centres and smaller provincial towns, which could be read as a urban-rural or centre-periphery cleavage at the sub-regional level. Whilst the main cities (capoluoghi) reacted mildly to the call for territorial mobilization, provincial communities were much keener. As shown in Figure 4, there was a considerable difference in levels of turnout between main cities and provincial towns. In Lombardy turnout in the capoluoghi was 10 percentage points lower than in the provincial areas. In Veneto the gap was even greater, 13 percent. If only the inhabitants of the main Venetian cities had voted, the referendum would have not passed the 50 percent threshold and, consequently, would have not been valid. This suggests that territorial mobilization in both contexts was far from being geographically homogeneous and aggregate results may hide important differences and tensions existing at the sub-regional level. This is true even in a region like Veneto, where, due to its socio-economic conditions, support for autonomy was expected to be more evenly spread. Yet, Tentoni (2018) shows that electoral differences between cities and peripheries have been historically important in the Italian context and do not only derive from socio-economic factors but also from long-term cultural and political dynamics. 
In comparison with the Catalan case, where Barcelona has traditionally been less proautonomy or pro-independence than the rest of the region ${ }^{8}$, it seems that regional territorial mobilization is usually more appealing to peripheral communities. Indeed they may consider central institutions as too remote and unaccountable, uninterested in the details of local governance and more sensitive to the needs of larger urban conglomerates. Strengthening meso-level institutions could therefore be seen by smaller communities as a solution to facilitate their access to decision-making processes.

\section{[Figure 4 here]}

In short, the evidence presented here suggests that an analysis based on the aggregate share of votes cast in favour of autonomy does not account for considerable differences in the levels of participation between and within regions. Firstly, even though the Yes vote won more than 90 percent of the vote in both regions, turnout figures indicate that autonomy is a much more salient issue in Veneto than in Lombardy and this may be explained not only by cultural and political legacies but also by socio-economic and geographical factors (for instance, proximity to and competition from special statute regions). Secondly, far from being political monoliths, regions may also be characterized by significant internal variation. Even a region like Veneto, which overall expressed a strong support for autonomy, appears to be internally divided as the strong differences in turnout between cities and provinces indicate. A more nuanced interpretation of the results allows also a better understanding of the political and institutional effects of the vote, which are assessed in the next section.

\section{After the Referendums: Political and Institutional Consequences}

The Lombardy and Veneto autonomy referendums have had important political and institutional consequences, shedding light on both latent and new 'fractures'. From a political 
perspective, they have revealed a growing gap between parties at regional and national level. As emphasized in our analysis, the NL was one of the political actors that dominated the debate on autonomy in Lombardy and Veneto. Whilst some political commentators warned that the success of the Yes camp could have been read as a 'NL victory' and exploited by the party to widen its appeal, the results had a more divisive impact in practice. The turn towards a nativist-nationalist approach by the party on the national stage and the de facto abandonment of the 'regionalist cause of the North' (Albertazzi, Giovannini and Seddone, 2018) certainly played a key role. This emphasizes the presence of latent tensions within the $\mathrm{NL}$, especially between the factions of the party more aligned to its new ideological turn, and those closer to its original regionalist stance.

Another key political consequence of the referendum concerns its impact on the Democratic Party. The party, which, at the time of the referendums, controlled central government, was internally divided. In particular, a vertical split between national leadership and local and regional representatives of the party emerged. Whereas the then national leader, Matteo Renzi, labelled the autonomy referendum as useless (D'Attino, 2017), as previously mentioned, PD mayors in Lombardy joined forces in the TAL network, actively campaigning for autonomy. This suggests that territorial mobilization and the launch of pro-autonomy campaigns may produce (or accelerate) a process of 'stratarchization' and territorial differentiation within state-wide parties (Carty, 2004). Calls for greater organizational and programmatic differentiation from the centre and the development of alternative constitutional goals may therefore affect the internal cohesion of political parties that are formally cross-territorial (Hepburn, 2010). 
From an institutional perspective, the Lombardy and Veneto referendums could impact in a substantial way on the Italian decentralized system, leading to further fragmentation and asymmetries. In many respects, the referendums have put under the spotlight the question of regional autonomy, with the potential to widen this across all Italian regions - thus giving new impetus to the implementation of Article 116 Clause 3 of the Italian constitution, which had remained dormant for several years.

Indeed, in the wake of the referendums, Lombardy and Veneto as well as Emilia-Romagna entered a process of negotiations with central government between November and December 2017. But these regions used different approaches. Whilst the results of consultative referendums could be seen as giving Lombardy and Veneto more contractual leverage at the negotiation table, in line with the differences highlighted in our analysis, the two regions did not 'join forces'. Shortly after the vote, Veneto regional government took a bottom-up approach, and passed the proposal for a 'national law of regional initiative' to be presented to Parliament, including 'details for the recognition of further regional autonomy for Veneto, putting into effect Art.116', with a view to keep most of the regional income inhouse (Giunta Regionale Veneto, 2017 - subsequently approved by the regional assembly). This was passed onto the Italian Prime Minister and the Minister for Regional Affairs who, acknowledging the compatibility of such request with the Constitution, opened officially unilateral negotiations. Meanwhile, Lombardy and Emilia-Romagna entered jointly the first phase of the negotiations for more autonomy, adopting a more 'institutional' approach giving a mandate, through deliberations of their respective Assemblies, to their regional governors to enter negotiations with central government. Eventually, in February 2018 the Minister for Regional Affairs and Autonomies and the regional governors signed three distinct preliminary agreements. Although including some elements of differentiation, these 
identified a number of shared 'priority areas' (Labour Policy, Education, Health, Environment, international and EU relations).

The next step (i.e. the preparation of a Bill to put before Parliament) was delayed by the general election of March 2018. The 'contract' signed by the new Five Star Movement/Lega coalition government did include the objective of quickly concluding the on-going negotiations with regions. Accordingly, the new Regional Affairs Minister, Erika Stefani, reiterated that settling the issue of increased regional autonomy is one of her priorities. She also stated that 'the objective of the government is to prepare individual Bills for the concession of further autonomy, based on regional specificities' adding that 'this is a system of "differentiated autonomy", and so too the legislative answer given to each region has to be differentiated - but the technical frame and legislative form will be the same for all the regions' (Chamber of Deputies, 2018). Interestingly, this claim seems to emphasise the possibility to prompt 'virtuous competition' between territories.

However, as of December 2018, the government has taken no further step and, as a result, Lombardy, Veneto and Emilia-Romagna governors sent a joint letter to the Prime Minister to prompt a swift conclusion to the process (Regione Emilia-Romagna, 2018). Finally, the path opened by Lombardy, Veneto and Emilia-Romagna has had a spillover effect. Out of the other 12 ordinary statute regions, seven have given a mandate to their governor to ask central government to enter negotiations for further autonomy (Campania, Liguria, Lazio, Marche, Piedmont, Tuscany and Umbria); three have started preliminary initiatives in a similar direction (Basilicata, Calabria and Apulia); whilst two (Abruzzi and Molise) have not taken any action (Senate Research Centre, 2018). 
Firstly, this suggests that the autonomy referendums seem to be having the effect of strengthening the competitive character of Italian regionalism (Keating, 2017; Keating, 1997) - whereby individual, or small groups of regions, seek to gain the best possible deal with the government for themselves. Crucially, despite the predicaments of central government, this process could foster a market-type form of competitions among regions for further autonomy that could lead to: i) convergence between stronger/better performing regions that currently have ordinary statute and special statute regions; ii) a vicious process of divergence between 'winners' and 'laggards' within the ordinary statute regions - which could set new divides as well as widen existing cleavages.

Secondly, and related to this, the referendums have set a precedent in what could be characterised as an uneven 'race towards autonomy', reducing the likelihood of 'convergence' within the already highly diversified regional autonomy framework in Italy. Some commentators argue that the path entered by Lombardy, Veneto and Emilia-Romagna with their agreement on shared priority areas could lead to a degree of 'linear asymmetry' prompting other regions to follow suit by proposing similar initiatives of 'parallel differentiation'. This would thus encourage an evolution of the Italian system of regionalism towards a new, but more advanced, symmetry (Ferrara, 2018). However, it remains to be seen whether this will be the case. The prospect of having individual legislation for each region suggests that there is the possibility to inscribe, and therefore legitimise, some forms of regional differentiation. A key point, which will have to be addressed once/if the government implements the individual agreements, concerns their funding. If diversified fiscal powers were to be granted to individual or small groups of regions, this would see a reduction in the national redistribution of resources, thus detracting from territorial solidarity and putting under threat the overall stability of the system (as it happened Spain, for instance). 
Remarkably, so far the debate on the implementation of asymmetric regionalism has not been matched by an adequate rethinking/reform of the central state - and this could have a negative impact on the 'unifying nodes' that hold the country together. Finally, differentiated regionalism could also foster either forms of 'emotive secession' or even centrifugal dynamics in regions with a strong cultural capital that perceive themselves simultaneously as 'economic centres' and 'political peripheries' (Diamanti, 2017) on the national stage (e.g. Veneto) especially if central government proves unable/unwilling to respond adequately to their (fiscal) autonomy requests.

\section{Conclusion}

This article has sought to assess recent developments in Italian regionalism by considering the two autonomy referendums in Veneto and Lombardy held in October 2017. Our study was based on three levels of comparison: across countries, across regions and within regions. A comparative analysis including all regional referendums held in Europe since 1970 has allowed us to contextualize the two cases. We have highlighted that both Venetian and Lombard referendums are quite peculiar in the European context since they were unilaterally promoted by regional governments (within a constitutionally legitimate framework) and aimed at starting a process rather than ratifying new legislation previously agreed by different institutional levels. At the same time, we have noticed substantial differences between the two regions not only in the process that led to the referendums but also in their results. Between the two, only Veneto comes closer to other cases of 'strong' regionalism (or 'substate nationalism') such as Scotland, Catalonia and the Basque Country, characterized by diffuse support for autonomy (and, in some cases, even independence). Socio-economic 
factors, political competition, the politicization of regional identity and institutional legacies all seem to contribute to an explanation of cross-regional differences.

We have also shown that regions may be characterized by significant internal variation in their territorial mobilization. In particular, we can observe a significant gap between urban areas and peripheries, which seems to replicate a 'centre-periphery' cleavage at the regional level. This latter point is often neglected by the literature, which tends to consider regions as political 'monoliths'. A more nuanced approach to the study of regionalism should not only focus on regional-central relations but should also account for tensions within regions (e.g. regional vs. local levels and cities vs. provinces). Lastly, our analysis has indicated that, when successful, regional referendums might legitimize demands for more autonomy and trigger a competitive process, which could lead to more cross-regional differentiation and territorial fragmentation. Italy does not stand alone in this respect, as the cases of Spain and the UK clearly demonstrate. 


\section{Notes}

${ }^{1}$ This category also includes provinces, districts and sub-state nations.

${ }^{2}$ We exclude the 2014 Scottish independence referendum, as this does not fit within our definition. Scotland did get further autonomy, or 'devo max'. However, strictly speaking, this was not the result of the vote itself, as the ballot simply asked whether Scotland should become an independent nation, and no question was posed as to whether it should get further devolution (indeed, central government refused for this latter option to be included). Thus, 'devo max' was offered by Westminster only after the vote had taken place, as a way to respond to the momentum generated by the referendum. As such, increased autonomy did not result from a referendum victory, as per our definition.

${ }^{3}$ An attempt was made by Lombardy between 2006 and 2007 but it did not lead to a referendum because the centre-left national government collapsed and the centre-right, including the NL, was back in power and could then promote pro-federalist reforms (including law 42/2009 on fiscal federalism) from central government.

${ }^{4}$ Examples of Lombard NL leaflets can be found here https://bit.ly/2G6MAR6.

${ }^{5}$ Municipalities with more than 15,000 inhabitants (no complete data are available for smaller municipalities).

${ }^{6}$ We focus on turnout because we observe significant differences in levels of participation not only between the two regions, as shown above, but also within the two regions - whilst the percentage of Yes vote is much more territorially homogeneous.

${ }^{7}$ A logged transformation of these variables is used, since their distribution is highly skewed and wide.

${ }^{8}$ Barcelona is the stronghold of Ciudadanos, a party that became politically active in 2006, canvassing for a 'No' vote in the Catalan referendum on the new autonomy statute (Rodríguez Teruel \& Barrio, 2016). Today it is the leading party of the anti-independence front. 


\section{References}

Albertazzi, D., Giovannini, A. \& Seddone, A. (2018). 'No regionalism please, we are Leghisti!' The transformation of the Italian Lega Nord under the leadership of Matteo Salvini. Regional \& Federal Studies, 28(5), 645-671

Anastasio, G. (2017, September 21). Lombardia autonoma, asse fra Maroni e Sindaci PD. II Giorno. Retrieved from https://goo.gl/kFA5TN

Anderson, B. (1991). Imagined Communities: Reflections on the Origin and Spread of Nationalism. London: Verso.

Atkins, J. (2018). Conflict, Co-operation and the Rhetoric of Coalition Government. Basingstoke: Palgrave Macmillan.

Bogdanor, V. (2001). Devolution in the United Kingdom. Oxford and New York: Oxford

Carty, R. K. (2004). Parties as Franchise Systems: The Stratarchical Organizational Imperative. Party Politics, 10(1), 5-24.

Ceccarini, L. \& Bordignon, F. (2017). Referendum on Renzi: The 2016 Vote on the Italian Constitutional Revision. South European Society and Politics, 22(3), 281-302.

Cento Bull, A. \& Gilbert, M. (2001). The Lega Nord and the Northern Question in Italian Politics. Basingstoke: Palgrave MacMillan.

Chamber of Deputies (2018), Official Minutes of the Meeting of the Deputies Chamber Held on 11 July 2018. Retrieved from:

http://www.camera.it/leg18/410?idSeduta=0024\&tipo=stenografico

Chambers, S. (2001). Constitutional Referendums and Democratic Deliberation. In M. Mendelsohn \& A. Parkin (Eds.), Referendum Democracy: Citizens, Elites and Deliberation in Referendum Campaigns (pp. 231-257). Basingstoke: Palgrave Macmillan.

Colino, C. (2009). Constitutional Change Without Constitutional Reform: Spanish Federalism and the Revision of Catalonia's Statute of Autonomy. Publius: The Journal of Federalism 39(2), 262-288.

Corriere del Veneto (2017, July 14). Autonomia, Zaia lancia la campagna per il Sì al referendum di ottobre. Corriere del Veneto. Retrieved from https://goo.gl/wXbLha

D’Attino, D. (2017, September 7). Padova, Renzi abbraccia Giordani e attacca Zaia sul referendum. Corriere del Veneto. Retrieved from https://goo.gl/GuJKeH 
Demos \& Pi (2014, March). I/ referendum per l'indipendenza in Veneto. Demos \& Pi Research Briefs. Retrieved from http://www.demos.it/a00970.php

Diamanti, I. \& Riccamboni G. (1992). La parabola del voto bianco: elezioni e società in Veneto. Vicenza: Neri Pozza

Diamanti, I. (1996). Il Male del Nord. Lega, Localismo, Secessione. Roma: Donzelli.

Diamanti, I. (2017a, October 24). Diversi dal Nord Est. La Repubblica. Retrived from https://goo.gl/ycKnMD

Diamanti, I. (2017b, May 16). Ecco perchè Zaia piace. Demos \& Pi Report: Osservatorio Nord Est. Available from http://www.demos.it/2017/pdf/432687_20170516_zaia.pdf

Fargion, V. (2005). From the southern to the northern question. Territorial and social politics in Italy. In N. McEwen \& L. Moreno (Eds.), The Territorial Politics of Welfare (pp. 127-147). London and New York: Routledge.

Ferrara, A. (2018, March). Regionalismo asimmetrico: pre-intesa delle Regioni EmiliaRomagna, Lombardia e Veneto con il governo Gentiloni. ISSiRFA - Institute for the Study of Regionalism, Federalism and Self-Government. Retrieved from: https://bit.ly/2UzgBfE

Ginsborg, P. (1996). Explaining Italy's Crisis. In S. Gundle \& S. Parker (Eds.), The New Italian Republic. From the Fall of the Berlin Wall to Berlusconi (pp. 19-39). London: Routledge.

Giovannini, A. (2014, April 7). Arrivederci, Veneto?. Open Democracy. Retrieved from https://goo.gl/hdLPwm

Giunta Regionale Veneto (2017), Progetto di Legge Statale N. 43, 23 October 2017

Gray, C. (2016). Nationalist Politics and Regional Financing Systems in the Basque Country and Catalonia. Bilbao: Foral Treasury Doctoral Thesis Collection.

Hepburn, E. (2010). Using Europe: Territorial party strategies in a multi-level system. Manchester: Manchester University Press.

Hooghe, L., Marks, G. \& Schakel, A. (2010). The Rise of Regional Authority: a comparative study of 42 democracies. Abingdon and New York: Routledge.

Keating, M. (2017). Contesting European Regions. Regional Studies, 51(1), 9-18 
Keating, M. (2013). Rescaling the European State: The Making of Territory and the Rise of the Meso. Oxford and New York: Oxford University Press.

Keating, M. (1997). The Invention of Regions. Political Restructuring and Territorial Government in Western Europe. Environment and Planning C: Government and Policy, 15, 383-398

Kleinschmager, R. (2013). Le référendum sur la collectivité territoriale d'Alsace du 7 avril 2013. Revue d'Alsace, 139, 401-420.

La Repubblica (2018, January 11). Piemonte, avviato il processo di autonomia: primo passo verso la macro-regione del Nordovest, La Repubblica Torino. Retrieved from https://goo.gl/sb57u1

La Repubblica (2017, September 16). Referendum Lombardia, Pisapia prende le distanze da Gori. La Repubblica Milano. Retrieved from https://goo.gl/ho5V6R

Lombardy Region (2017). Scopri perchè la Lombardia è speciale. Online brochure. Retrieved from https://goo.gl/MNc8Mw

Mingoia, M. (2017, October 21). Lombardia e Veneto al voto. Referendum per l'autonomia ma alla Lega saltano in nervi. Quotidiano.net. Retrieved from https://goo.gl/Zqqgg6

Mitchell, J. (2010). Devolution in the United Kingdom. Manchester: Manchester University Press.

Montanari, A. (2017, June 27). Lombardia, referendum sull'autonomia: i sindaci disinnescano la Lega. La Repubblica - Milano. Retrieved from https://goo.gl/8KtjgY

Oklopcic, Z. (2012). Independence Referendums and Democratic Theory in Quebec and Montenegro. Nationalism and Ethnic Politics, 18(1), 22-42.

Palermo, F. \& Wilson, A. (2013). The multi-level dynamics of state decentralization in Italy. Comparative European Politics, 12(4-5), 510-530.

Porcellato, N. (2017a, December 6). I tempi dell'autonomia, la prevalenza degli scettici. Demos \& Pi Report: Osservatorio Nord Est. Retrieved from http://www.demos.it/a01458.php

Porcellato, N. (2017b, May 16). Un plebisicito del Veneto per il governatore Zaia. Demos \& Pi Report: Osservatorio Nord Est. Retrieved from http://www.demos.it/a01386.php 
Putnam, R. (1993). Making Democracy Work: Civic Traditions in Modern Italy. Princeton: Princeton University Press.

Regione Veneto (2017). Referendum sull'autonomia del Veneto. Retrived from: https://goo.gl/RtY4xZ

Regione Emilia-Romagna (2018, 30 November). 'Emilia-Romagna, Lombardia e Veneto chiedono di accelerare il negoziato dell'autonomia differenziata'. Retrieved from: https://bit.ly/2C5bg8v

Rodríguez T.J. \& Barrio, A. (2016). Going National: Ciudadanos from Catalonia to Spain. South European Society and Politics, 21(4), 587-607

Senesi, A. (2017, September 17). Milano, Pisapia: No al Referendum autonomia. È una truffa. Corriere Della Sera - Milano. Retrieved from https://goo.gl/6piJVP

Senate Research Service (2018, July). Verso un regionalismo differenziato: le Regioni che non hanno sottoscritto accordi preliminari con il Governo. Dossier n. 45. Retrieved from: https://bit.ly/2QOlyc6

Luca Tentoni (2018). Capitali regionali. Le elezioni politiche nei capoluoghi di regione 19462018. Bologna: Il Mulino.

Trigilia, C. (1986). Grandi partiti e piccole imprese. Comunisti e democristiani nelle regioni a economia diffusa. Bologna: il Mulino.

Trigilia, C. (1991). Le subculture politiche territoriali. Quaderni della Fondazione Feltrinelli, Milano

Vandelli, L. (2014). I/ Governo Locale. Bologna: II Mulino.

Vampa, D. (2016). The Regional Politics of Welfare in Italy, Spain and Great Britain. Basingstoke: Palgrave.

Vampa, D. (2017). Matteo Salvini's Northern League in 2016: Between Stasis and New Opportunities. In A. Chiaramonte \& A. Wilson (Eds.), Italian Politics 2016 (pp. $32-50$ ). Oxford and New York: Berghahn Books.

Vassallo, S. (Ed). (2013). Il divario incolmabile: Rappresentanza politica e rendimento istituzionale nelle regioni italiane. Bologna: il Mulino. 
Willett, J. \& Giovannini, A. (2014). The Uneven Path of English Devolution. Top Down vs. Bottom Up Regionalism in England - Cornwall and the North East Compared. Political Studies, 62(2), 343-360.

Wyn Jones, R. \& Scully, R. (2012). Wales Says Yes: Devolution and the 2011 Welsh Referendum. Cardiff: University of Wales Press. 


\section{TABLES}

Table 1. Reasons for holding autonomy referendums

\begin{tabular}{|l|l|l|l|l|}
\hline & Ratifying reform? & $\begin{array}{l}\text { Introducing new } \\
\text { political } \\
\text { institutions }\end{array}$ & $\begin{array}{l}\text { Transferring } \\
\text { policy making } \\
\text { powers }\end{array}$ & $\begin{array}{l}\text { Transferring fiscal } \\
\text { powers }\end{array}$ \\
\hline Wales $\mathbf{1 9 7 9}$ & Yes & Yes & Yes & No \\
\hline Scotland $\mathbf{1 9 7 9}$ & Yes & Yes & Yes & No \\
\hline Catalonia 1979 & Yes & Yes & Yes & Yes \\
\hline $\begin{array}{l}\text { Basque Country } \\
\mathbf{1 9 7 9}\end{array}$ & Yes & Yes & Yes & Yes \\
\hline Galicia $\mathbf{1 9 8 0}$ & Yes & Yes & Yes & Yes \\
\hline $\begin{array}{l}\text { Andalusia } \mathbf{1 9 8 0}- \\
\mathbf{1 9 8 1}\end{array}$ & Yes (1981) & Yes & Yes & Yes \\
\hline Wales $\mathbf{1 9 9 7}$ & No & Yes & Yes & No \\
\hline Scotland $\mathbf{1 9 9 7}$ & No & Yes & Yes \\
\hline Corse 2003 & Yes & Yes & Yes & Yes \\
\hline $\begin{array}{l}\text { North-East } \\
\text { England } 2004\end{array}$ & No & Yes & Yes & No \\
\hline Catalonia $\mathbf{2 0 0 6}$ & Yes & No & Yes & Yes \\
\hline Andalusia 2007 & Yes & No & Yes & Yes \\
\hline Wales 2011 & Yes & No & Yes & No \\
\hline Alsace 2013 & Yes & Yes & No & No \\
\hline Lombardy 2017 & No & No & Yes & Yes \\
\hline Veneto $\mathbf{2 0 1 7}$ & No & No & Yes & Yes \\
\hline
\end{tabular}


Table 2. The results of the autonomy referendums in Lombardy and Veneto (absolute number of voters in brackets)

\begin{tabular}{|l|l|l|l|}
\hline & Yes & No & Turnout \\
\hline Lombardy & $96.02 \%$ & $3.98 \%$ & $38.11 \%$ \\
& $(2,875,438)$ & $(119,051)$ & $(3,017,707)$ \\
\hline Veneto & $98.1 \%$ & $1.9 \%$ & $57.2 \%$ \\
& $(2,273,985)$ & $(43,938)$ & $(2,328,949)$ \\
\hline
\end{tabular}

Sources: Lombardy Region (goo.gl/abuF3D), Veneto Region (goo.gl/RtY4xZ) 
Table 3. Determinants of referendum turnout in Venetian and Lombard municipalities

\begin{tabular}{|l|l|l|}
\hline & Coefficient & Standardized \\
\hline Veneto & $20.265(0.812)^{* * *}$ & 0.883 \\
\hline NL (2014) & $0.968(0.167)^{* * *}$ & 0.373 \\
\hline PD (2014) & $0.226(0.183)$ & 0.095 \\
\hline FI (2014) & $0.544(0.216)^{* *}$ & 0.13 \\
\hline M5S (2014) & $0.161(0.172)$ & 0.047 \\
\hline Per capita income (log) & $7.668(3.151)^{* *}$ & 0.087 \\
\hline Population Size (log) & $-2.751(0.486)^{* * *}$ & -0.161 \\
\hline Constant & $-42.479(37.601)$ & \\
\hline Adj R-Squared & \multicolumn{2}{|c|}{0.902} \\
\hline N & \multicolumn{2}{|c|}{153} \\
\hline
\end{tabular}

${ }^{*} p<0.1 ; * * p<0.05 ; * * * p<0.01$ 
Figure 1. Autonomy referendums: at what level are they promoted?

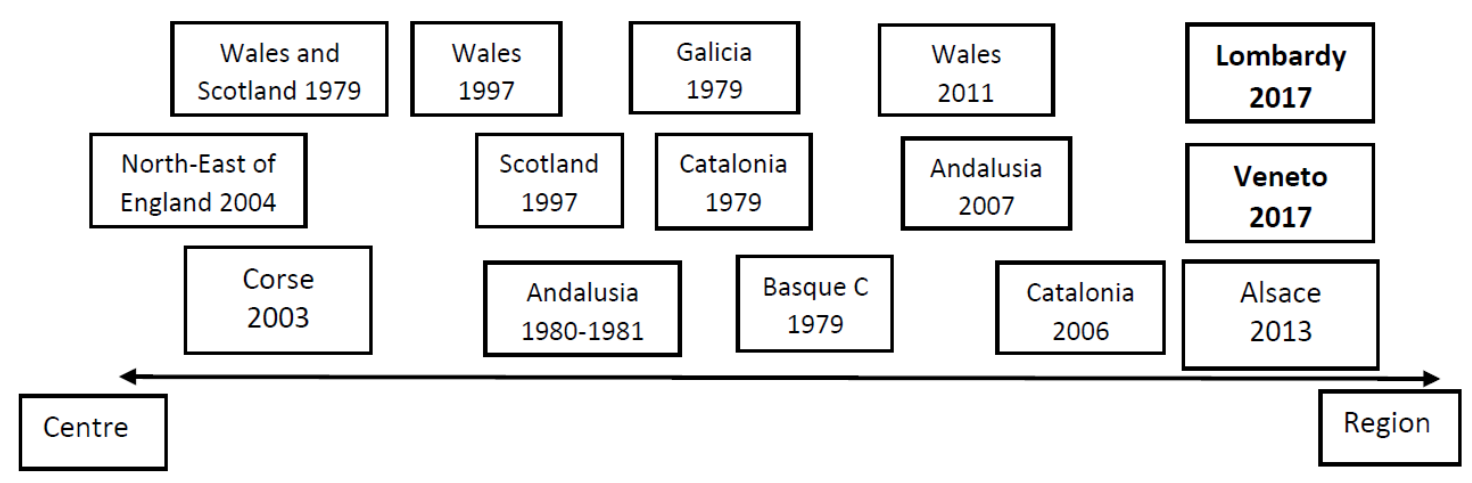


Figure 2. Linking institutional, socioeconomic and political factors to autonomy referendums.

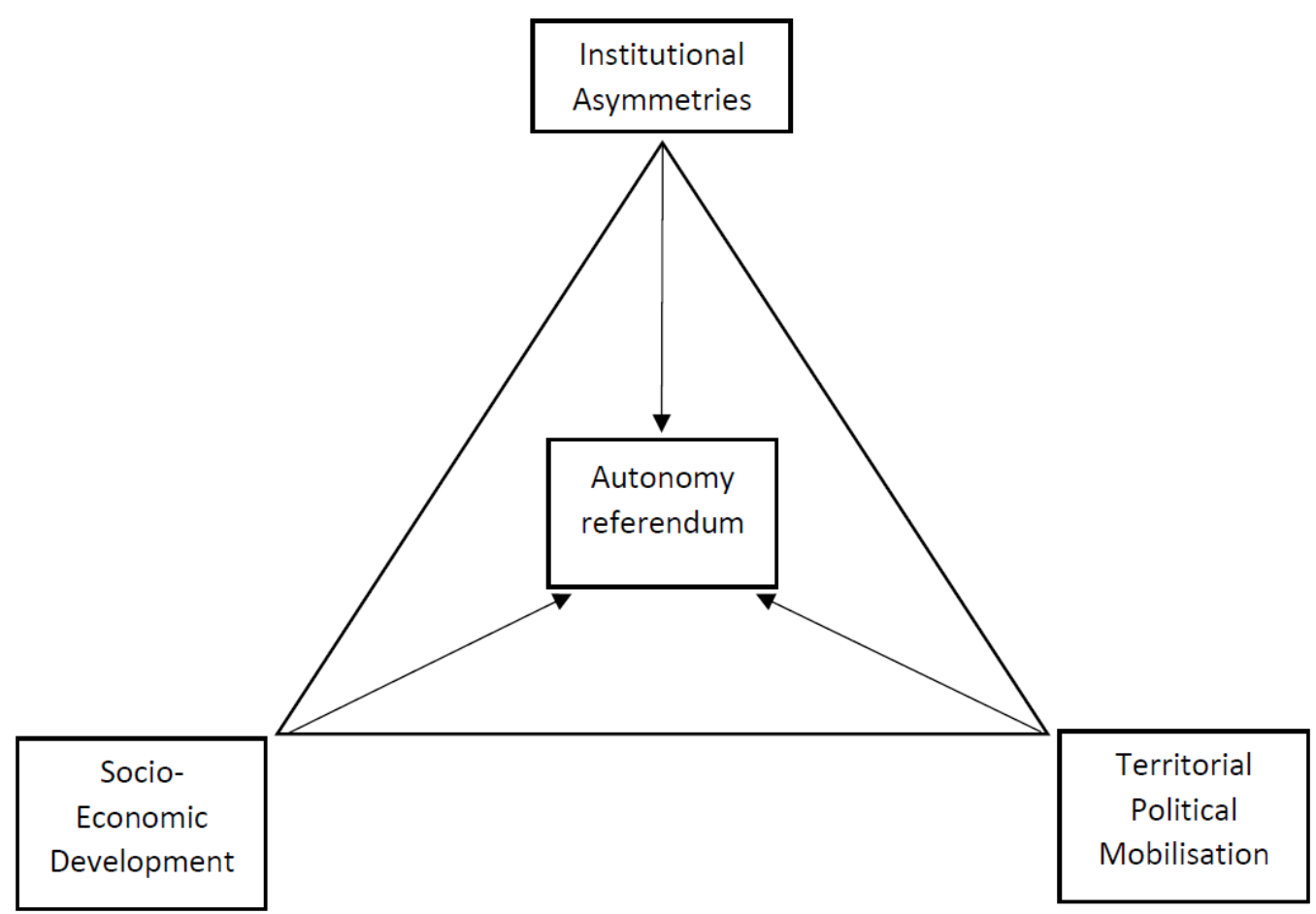


Figure 3. Mobilization and support for autonomy: the Lombard and Venetian referendums in comparative perspective

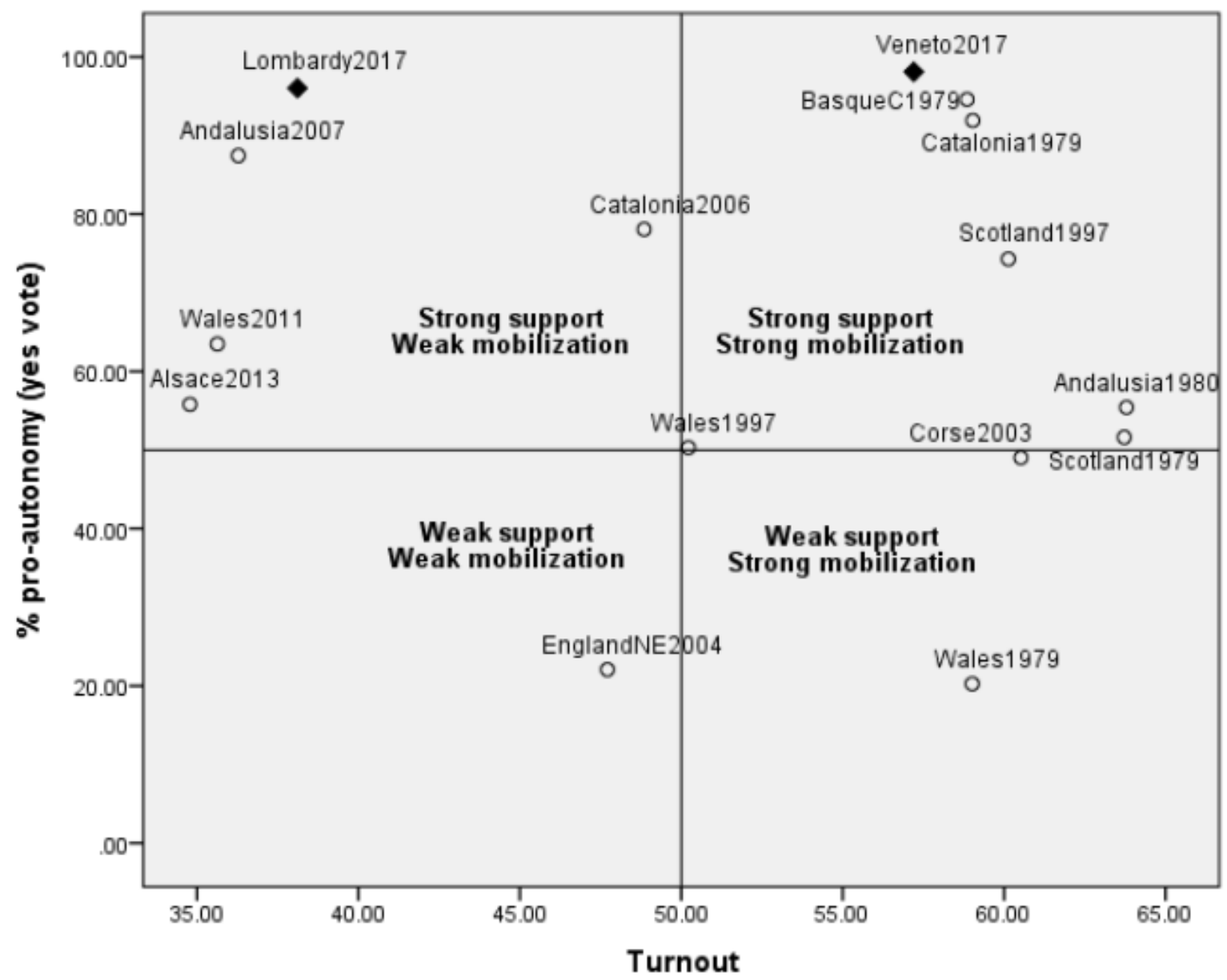


Figure 4. Turnout: comparing main cities (capoluoghi) with the rest of the region

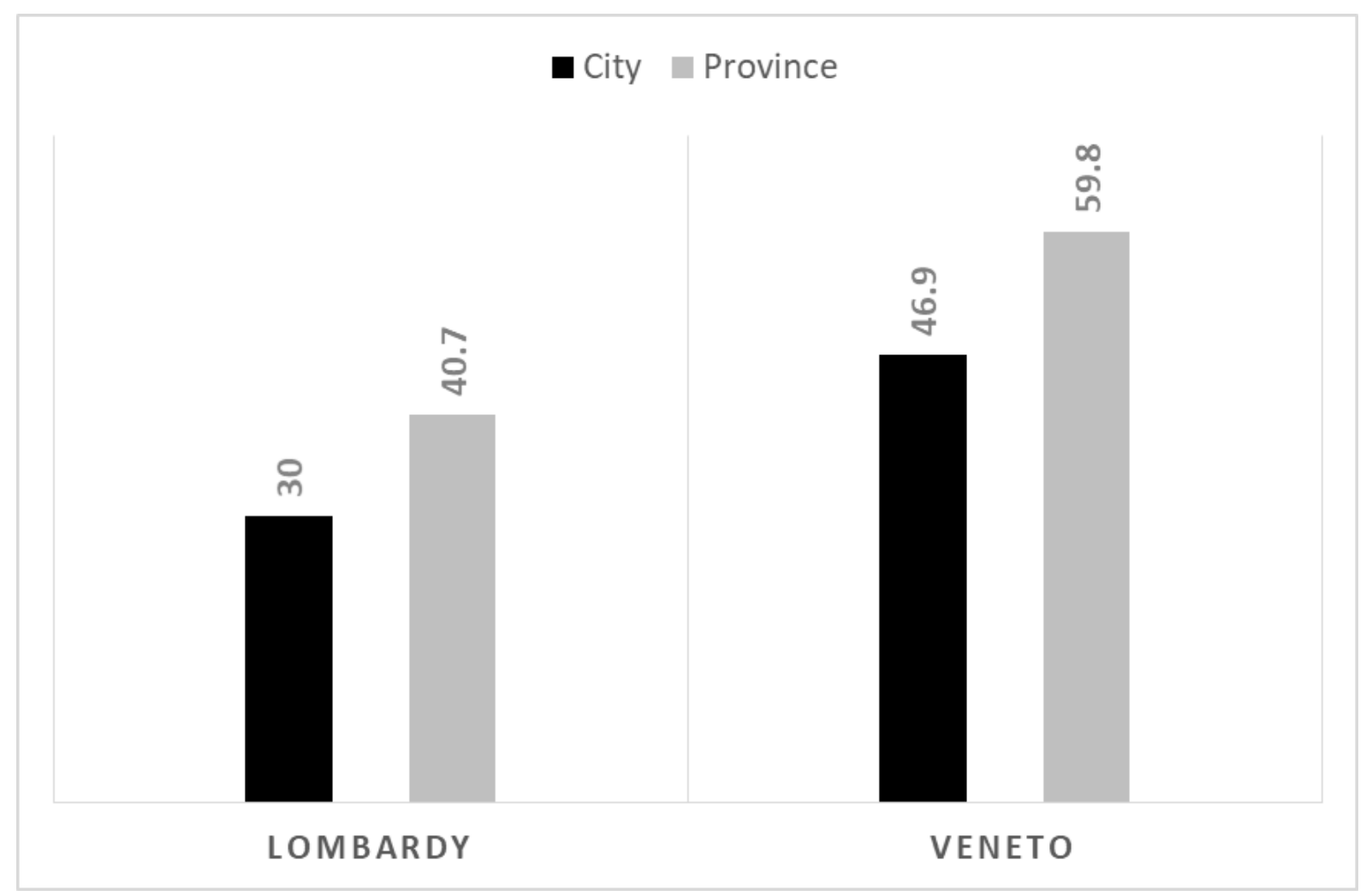

